\title{
CEPAEA NEMORALIS (L.) IN POLAND: AN OPEN ACCESS DATABASE OF THE SHELL COLOUR AND BANDING POLYMORPHISM
}

\author{
MAŁGORZATA OŻGO ${ }^{1 *}$, ROBERT A. D. CAMERON ${ }^{2,3}$, MAGDALENA MARZEC $^{4}$, \\ BEATA M. POKRYSZKO ${ }^{5}$, ANNA SULIKOWSKA-DROZD ${ }^{6}$
}

\begin{abstract}
${ }^{1}$ Department of Evolutionary Biology, Kazimierz Wielki University, Al. Ossolinskich 12, Bydgoszcz 85-093, Poland (e-mail: mozgo.biol@interia.pl); (1) https://orcid.org/0000-0002-9999-8450

${ }^{2}$ Department of Animal and Plant Sciences, University of Sheffield, Sheffield S10 2TN, United Kingdom (e-mail: r.cameron@sheffield.ac.uk)

${ }^{3}$ Department of Zoology, Natural History Museum, London SW7 5BD, United Kingdom

${ }^{4}$ Suwalski Landscape Park, Malesowizna 24, 16-404 Jeleniewo, Poland

(e-mail: magdamarzec@poczta.onet.pl); (1) https://orcid.org/0000-0002-8366-6099

${ }^{5}$ Museum of Natural History, Wrocław University, Sienkiewicza 21, 50-335, Wrocław, Poland

(e-mail: beata.pokryszko@uwr.edu.pl); (1) https://orcid.org/0000-0003-3631-3044

${ }^{6}$ Department of Invertebrate Zoology and Hydrobiology, Faculty of Biology and Environmental Protection,

University of Łódź, Banacha 12/16, 90-237 Łódź, Poland (e-mail: anna.drozd@biol.uni.lodz.pl);

(1) https://orcid.org/0000-0002-2865-7130

*corresponding author
\end{abstract}

\section{INTRODUCTION}

Studies on the shell colour and banding polymorphism in the land snail Cepaea nemoralis (L.) have a history going back for more than a century. It has become, intermittently, a model organism for the study of evolutionary processes within species. Summary reviews of these studies are given by JONES et al. (1977), COOK $(1998,2017)$ and CAMERON (2016), while OŻGO (2008) discusses outstanding problems for which it is a suitable study organism.

Many patterns of variation have been found. Some clearly show the effects of natural selection relating to habitat and predation and to the effects of macro-and micro-climate, but others support the idea that founder effects and genetic drift play an important part in explaining the constitution of par- ticular populations and of differences among them. As a model, $C$. nemoralis has been instrumental in exposing the true complexity of evolutionary processes.

While there can be no doubt that experimental and behavioural studies have significantly improved our understanding of the complex interactions that might explain this variation, most of our knowledge relates to field surveys in time and space. Some local studies, of which CAIN \& SHEPPARD (1954) is the classic, have detected effects of habitat, while others have revealed connections to climate or to the way in which landscape history gives rise to founder effects or establishes a balance between migration and genetic drift (CAMERON et al. 2009). 
There are, however, two kinds of study that have been particularly useful. Where sample sites can be accurately located after an interval of time, any changes can be detected, and related to changes in habitat or climate. On a larger scale, the aggregation of data from many studies over large areas can relate variation to many factors and examine geographical variation in their effects. While there were earlier analyses of this kind (JONES et al. 1977), a comprehensive citizen science project, the Evolution Megalab (WORTHINGTON et al. 2012) set out to create a range-wide database incorporating both all historic records and those added by contributors in the 21 st century. Both time and space could be examined, and the results were announced in SILVERTOWN et al. 2011). It provoked more detailed studies of variation over time (e.g. CAMERON \& COOK 2013) that have demonstrated selective changes.

At the time the Evolution Megalab was set up and run, there were relatively few records from Poland, although interest was increasing (OŻGO 2008). Results of many local and regional surveys in Poland were published later (a full bibliography is given in OŻGO et al. 2019). Because C. nemoralis is a range-expanding species in many parts of Poland, its variation is of particular relevance to studies on founder effects, drift and migration, while at the same time there is evidence of very rapid selection in relation to habitat (OŻGO \& KINNISON 2008, OŻGO 2011).

Hence, it was appropriate to set up a database of Polish populations, and to solicit new records prior to attempting a nationwide analysis of the patterns revealed. This analysis, completed in 2017, considered 1,048 samples, widely distributed across the country (OŻGO et al. 2019). About 50 further records have been added since. While this database is available as supplementary material to OżGO et al. (2019), it lacks the precision of site locations actually available, and is not that easy to access for those without subscribing library facilities. We have therefore set up a specifically Polish database that is accessible to all, has the most detailed information that could be applied to all records, and, with checks on reliability, could be added to as more records, published or otherwise, were available.

It was originally intended to add records of polymorphism in the closely related Cepaea hortensis (Müller). Although the species is native and widely distributed in Poland, there are few records of adequate sample size, and the format of the database for this species would need to be different. In particular, earlier work on this species (CLARKE 1962) shows that accurate and consistent recording of band fusions are needed to analyse variation with habitat. These records are at present held by M. Ożgo and R. A. D. Cameron (among the moderators, see below). They can be added, possibly as a separate database, if there are sufficient records to justify it.

Experience with the Evolution Megalab (WORTHINGTON et al. 2012) demonstrated that recorders could confuse these two Cepaea species, which may co-exist. While they are usually easy to distinguish (WIKTOR 2004), C. hortensis can have a dark lip to the shell, and where both are present, juvenile snails cannot be used in the sample. To preserve the reliability of the database, new records will be entered only after moderation by any one of the team listed below.

The database belongs to the Polish Society of Malacologists (Stowarzyszenie Malakologów Polskich). A report on activity and usage will be made by any one of the moderators appointed by the Society at its Annual General Meeting. The Society will also approve the designation of new moderators when needed. The appointed moderators are listed below. Any changes will be added to this list, and the date on which the change was made will be noted. These names and email addresses will also be available in the database. Records for entry should be sent to any of them in the first instance.

Małgorzata Ożgo: mozgo@ukw.edu.pl Anna Sulikowska-Drozd: sulik@biol.uni.lodz.pl Beata Pokryszko: beata.pokryszko@uwr.edu.pl Magdalena Marzec: magdamarzec@poczta.onet.pl Robert Cameron: r.cameron@sheffield.ac.uk

This database is now available at http://cepaea. amu.edu.pl, hosted by Adam Mickiewicz University, Poznań. Details of its structure are given below, modified from the introduction in the website itself. The aim is to stimulate further recording and the repeat sampling of populations to study variation over time. All records are in the public domain, and may be used with acknowledgement of the source. Because the database is live, and will have more records added, any reference to the database should give the date on which it was accessed. Regardless of the date on which a sample was made, data will be entered in the sequence in which they are received and verified. 


\section{THE DATABASE}

\section{SOURCES}

Published records are taken directly from the papers cited. In all cases, only samples of 20 or more shells have been entered, and only those that conformed in terms of size of area sampled (OŻGO et al. 2019). Unpublished records have been made or checked by moderators. While further details are given under "reading the columns", the original records vary in the degree of detail they provide; the database provides the minimum data available for all.

\section{READING THE COLUMNS}

Column 0: the date on which the sample was added to the database. 10/09/2019 is the original date for setting up the database. Note that the date is for entry and not that of sampling, which is given in column 3.

Column 1 contains the unique identifying number for each entry. Samples 1-1,048 refer to all those used in the national survey reported in OżGO et al. (2019). These data are also given in the Supplementary Material (Appendix 1) of that paper, but with less information than shown here. Samples from 1049 onwards refer to authenticated data added since the results of the national survey were published. Later records will be added in sequence by the date on which they are entered, regardless of the date of sampling, so that each entry retains its unique identifying number in perpetuity.

Column 2 shows the source of the records. Names with a date refer to published sources other than OŻGO et al. (2019), or SILVERTOWN et al. (2011), which includes some but not all of those used in OŻGO et al. (2019). Names without a date refer to the contributors of the record. Full details are given after the reference list. Names in brackets after the first one given indicate student records made under supervision.

Column 3 gives the year in which the sample was made. In the case of some published surveys, a range is given.

Columns 4 and 5 give the longitude and latitude of the sample site in decimal degrees. Longitude precedes Latitude to facilitate mapping. Note: while many samples were located by GPS, some were marked on maps, from which the co-ordinates were measured. The level of precision will vary among samples.
Column 6 gives a locality name where it was provided, to make locating the sample easier.

Column 7 indicates the habitat in three categories: open (O), intermediate (I) and shaded (S). Open is defined as cover only of herbaceous vegetation, shaded as with complete or nearly complete canopy cover by woody plants, and intermediate as a mixture with some woody cover. Note: In the largely disturbed and anthropogenic habitats in which $C$. nemoralis is found, the intermediate category was hard to define. In the case of OżGO (2012), the category was not used. Analyses of the effect of habitat may be most reliable when sets of samples made by the same observer within a restricted region are used.

Column 8 gives the total number of $C$. nemoralis shells scored for shell colour and banding. Note: only records of 20 or more shells are included. The database is not a record of all finds of $C$. nemoralis in Poland.

Columns 9-18 give the number of shells in each major shell colour and banding category. $\mathrm{Y}$ - yellow; P - pink; B - brown; 0 - unbanded shells; 3 - midbanded shells (00300); 00345 - shells with the top two bands missing; 5 - all shells with at least one of the top two bands present, typically 12345 , but with one or more bands sometimes missing; $\mathrm{b}-$ (as $\mathrm{Bb}$ ) all brown shells in which banding is visible. Note 1: in some but not all studies the extent to which bands were fused together was noted. Because the scoring of fusions is harder to standardise than in the categories given above, it has been omitted here, but in local studies it has been shown to vary with habitat. Note 2: There are many minor variants of banding, the genetics of which are unknown. Shells showing 00045 are thus aggregated with 00345 , for example. Note 3: All brown banded shells have been placed in the same category; bands are often faint, and there is reason to think that there are interactions with shell colour that affect their expression. Note 4: all scored shells have been allocated to one of the major categories listed above. More details are available in some of the published accounts.

Column 19 leaves room for additional comments. This has sometimes been used to list brown 00300 and brown 12345 separately within the Bb category.

\section{ACKNOWLEDGEMENTS}

We are indebted to Professor ANDRZEJ LESICKI and the IT Centre of Adam Mickiewicz University, Poznań for facilitating and hosting the database. 


\section{REFERENCES}

References here are to those cited in the text. Others cited in the database itself are cited there and in OżGO et al. (2019).

CAIN A. J., SHEPPARD P. M. 1954. Natural selection in Cepaea. Genetics 39: 89-116.

CAmeron R. A. D. 2016. Slugs and snails. Collins New Naturalist, London.

Cameron R. A. D., CoOK L. M. 2013. Temporal morph frequency changes in sand-dune populations of Cepaea nemoralis (L.). Biological Journal of the Linnean Society 108: 115-122. https://doi.org/10.1111/j.10958312.2012.02008.x

CAmeron R. A. D., Pokryszko B. M., Horsák M. 2009. Contrasting patterns of variation in urban populations of Cepaea (Gastropoda: Pulmonata): a tale of two cities. Biological Journal of the Linnean Society 97: 27-39. https://doi.org/10.1111/j.1095-8312.2008.01187.x

Clarke B. C. 1962. Balanced polymorphism and the diversity of sympatric species. In: NichOLS D. (ed.). Taxonomy and geography. Systematics Association, London, pp. 47-70.

CoOK L. M. 1998. A two-stage model for Cepaea polymorphism. Philosophical Transactions of the Royal Society of London. Series B, Biological Sciences 353: 15771593. https://doi.org/10.1098/rstb.1998.0311

CoOK L. M. 2017. Reflections on molluscan shell polymorphisms. Biological Journal of the Linnean Society 121: 717-730. https://doi.org/10.1093/biolinnean/blx033

JONES J. S., LEITH B. H., RAWLINGS P. 1977. Polymorphism in Cepaea: a problem with too many solutions? Annual Review of Ecology and Systematics 8: 109-143. https:// doi.org/10.1146/annurev.es.08.110177.000545

OżGo M. 2008. Current problems in the research of Cepaea polymorphism. Folia Malacologica 16: 55-60. https:// doi.org/10.12657/folmal.016.009

OŻGO M. 2011. Rapid evolution in unstable habitats: a success story of the polymorphic land snail Cepaea nemoralis (Gastropoda: Pulmonata). Biological Journal of the Linnean Society 102: 251-262. https://doi. org/10.1111/j.1095-8312.2010.01585.x

OżGO M. 2012. Shell polymorphism in the land-snail Cepaea nemoralis (L.) along a west-east transect in continental Europe. Folia Malacologica 20: 181-235. https:// doi.org/10.2478/v10125-012-0015-1

OżGO M., KinNison M. T. 2008. Contingency and determinism during convergent contemporary evolution in the polymorphic land snail, Cepaea nemoralis. Evolutionary Ecology Research 10: 721-733.

Ożgo M., CAMERon R. A. D., HorsÁK M., POKryszKo B. M., CHUdAŚ M., CiCHY A., KACZMAREK S., KOBAK J., MARZEC M., MIERZWA-SZYMKOWIAK D., PARZONKO D., PYKA G., ROSIN Z., SKAWINA A., SOROKA M. SULIKOWSKA-DROZD A., SUROWIEC T., SZYMANEK M., TEMPlin J., URBAŃSKA M., ZAJĄ K., ZIELSKA J., ŻBIKOWSKA E., ŻOŁĄDEK J. 2019. Cepaea nemoralis (Gastropoda: Pulmonata) in Poland: patterns of variation in a range-expanding species. Biological Journal of the Linnean Society 127: 1-11. https://doi. org/10.1093/biolinnean/blz029

Silvertown J., COOK L. M., CAmeron R. A. D., DodD M., MCCONWAY K., WORTHINGTON J., SKELTON P., ANTON C., BOSSDORF O., BAUR B., SCHILTHUIZEN M., Fontaine B., SATtMANN H., Bertorelle G., Correia M., Oliveira C., PokryszKo B., Ożgo M., Stalažs A., Gill E., RAMmul Ü., SÓlymos P., FÉHeR Z., JUAN X. 2011. Citizen science reveals unexpected continental-scale evolutionary change in a model organism. PLoS ONE 6: e18927. https://doi.org/10.1371/journal. pone.0018927

WikTOR A. 2004. Ślimaki lądowe Polski. Mantis, Olsztyn.

WORTHINGTON J. P., SILVERTOWN J., COOK L. M., CAMERON R. A. D., DodD M., GreENWOOd J. M., MCCONWAY K., SKELTON P. 2012. Evolution MegaLab: a case study in citizen science methods. Methods in Ecology and Evolution 3: 303-309. https://doi.org/10.1111/j.2041210X.2011.00164.X

Received: September 16th, 2019

Accepted: November 25th, 2019

Published on-line: December 14th, 2019 